\title{
Relationships between father's age, birth order, family size, and need achievement
}

\author{
TONI FALBO \\ University of Texas at Austin, Austin, Texas 78712 \\ and \\ CHARLES L. RICHMAN \\ Wake Forest University, Winston-Salem, North Carolina 27109
}

\begin{abstract}
A study was conducted to test several hypotheses regarding the determinants of need achievement. In addition to predicting sex $(M>F)$ differences, the study predicted that father's age would be inversely related to need achievement. In addition, the effects of family size and birth order on achievement motivation were compared. Subjects were 1,092 undergraduates (785 males, 307 females). Need achievement was measured by the Edwards Personal Preference Schedule. The results indicate that father's age, sex, and family size were significantly related to need achievement. Younger fathers, males, and smaller families were associated with higher need achievement.
\end{abstract}

Factors affecting achievement motivation have inherent relevance to understanding individual differences in academic success. The present paper is concerned with the familial origins of achievement motivation, a topic that has received considerable attention (Atkinson, 1958; McClelland, 1961; McClelland, Atkinson, Clark, \& Lowell, 1953). More specifically, the purpose of the present study is to examine the impact of the age of the father, birth order, family size, and sex on the achievement motivation of the child.

The major theory underlying this study is that of McClelland et al. (1953). Basically, this theory states that achievement motivation is learned through repeated experiences in which positive or negative affect is associated with successful or unsuccessful (respectively) efforts at reaching a standard of excellence. Guided by this theory, previous investigators have studied the standards of behavior mothers impose on their children. Presumably, the imposition of reachable, but high, standards of behavior is conducive to the development of high achievement motivation. Supporting this notion, Winterbottom (1958) found that early demands for independence and mastery were related to higher levels of achievement motivation in 8- to 10-year-old boys. Subsequent research has sometimes supported, sometimes clouded this picture of the origins of achievement motivation. One of the problems appears to be the

The authors wish to thank George Byars and Charles Roper for their assistance in collecting and coding the data, and Jerome Kagan for his comments. This research was partially supported by U.S. Public Health Service Grant MH 21288 from the National Institute of Mental Health awarded to Charles L. Richman. Requests for reprints should be sent to Charles L. Richman, Department of Psychology, Wake Forest University, Winston-Salem, North Carolina 27109. conceptualization of independence training. Some construe it as indicating matemal rejection (McClelland, 1961); others see it as fostering self-care and autonomy and not achievement motivation (Child, Storm, \& Veroff, 1958; Rosen \& D'Andrade, 1959), while others make a distinction between instrumental vs. emotional independence (Stein \& Bailey, 1973). Overall, the research results about independence demands and achievement motivation have been mixed (V. J. Crandall, 1963). Nonetheless, in support of the McClelland (1961) theory, it should be noted that maternal acceleration (excessively high expectations regarding the child's behavior) has frequently been related to the actual achievements of the child (V. C. Crandall \& Battle, 1970; Kagan \& Freeman, 1963; Kagan \& Moss, 1962).

So far, the sources of achievement motivation considered have been restricted to the standards of behavior directly imposed on children by parents. Other forms of learning, namely, observational learning, could also be at work in the development of achievement motivation. For example, a number of investigators have demonstrated that achievement standards and behavior can be learned through imitation (Bandura, Grusec, \& Menlove, 1967; Mischel \& Liebert, 1966). Thus, it seems likely that the extent to which parents model achievement-oriented behavior is related to the child's acquisition of achievement motivation.

This article introduces a new variable, father's age, as a factor in the development of achievement motivation. It is argued here that younger fathers facilitate the development of achievement motivation in their children more than older fathers. This facilitation could occur in two ways. First, on the average, younger fathers would model higher levels of achievement motivation than 
older ones. This is supported by the finding that younger adults possess greater achievement motivation than older adults (Clemente \& Sayer, 1976; Shannan \& Sharon, 1965). Second, it is likely that younger fathers impose higher standards on their children than older ones. This is supported by research indicating that older fathers see their roles as benevolent overseers, while younger fathers see their roles as mentors (Nydegger, 1973). These age differences in the perception of the father role possibly lead younger fathers to impose higher standards on their children than do older fathers.

At this juncture, it is necessary to make the point that these predictions are limited to the middle class. It may be that extremely young fathers, who are more common in the lower class, do not have this facilitative impact on achievement motivation. Since this study represents the first effort at studying the impact of father's age on achievement motivation, the predictions and resultant survey sample are limited to members of the middle class. In so doing, the range of paternal ages and achievement motivation scores are limited. Not only is age at first birth related to social class, but so is achievement motivation. Although religion and ethnicity may alter the relationship, the general finding is that middle-class people exhibit more achievement motivation than either upper or lower class people (Douvan, 1958; McClelland, 1961; Rosen, 1958).

This study also introduces another variable into the constellation of familial variables that could influence achievement motivation. Specifically, the impact of family size on children's achievement motivation is considered. Overshadowed by birth order, family size has only recently been related to psychological variables, such as intelligence and achievement. Zajonc (1976) demonstrated that the family size effect was greater than the birth order effect on intelligence. Furthermore, Zajonc reported that the birth order effect (i.e., earlier borns excelling beyond later ones) was largely reversed by large age spacing between siblings. Breland (1974) reported similar findings with achievement scores. In view of the Breland (1974) and Zajonc (1976) results, it is hypothesized that family size will have greater impact on achievement motivation than birth order.

Finally, this study includes the sex of the child as a significant variable in predicting achievement motivation. One of the reasons frequently cited for the lowered achievements of females is that parents are more likely to treat boys than girls in ways conducive to the development of achievement motivation (Hoffman, 1972; Stein \& Bailey, 1973). Instead of examining sex differences in achievement motivation, however, research aimed at studying sex differences has concentrated on such topics as sex differences in arousal of achievement motivation (Alper, 1974; Stein \& Bailey, 1973), fear of success (Coudry \& Dyer, 1976; Tresemer, 1976), and self-confidence (Lenney, 1977). Because sex differences in all of these achievement-related areas have been found, it seems advisable to consider sex of the child in addition to the other familial variables in determining achievement motivation.

\section{METHOD}

\section{Subjects}

Subjects were 1,092 undergraduates ( 785 males, 307 females) from Wake Forest University in Winston-Salem, North Carolina, and the University of Texas at Austin. Surveys of the family incomes indicate that the students were predominantly middle class. Of the Wake Forest students, $90 \%$ came from families with annual incomes over $\$ 15,000$. Among University of Texas students, $67 \%$ came from families whose annual incomes are over $\$ 12,000$. Fifty-one subjects were omitted from the study because their fathers were deceased.

Subjects participated in a 30-min study entitled "You and Your Preferences." All subjects completed a brief questionnaire that requested background information about age, father's age, birth order, and number of siblings. Then a brief form of the Edwards Personal Preference Schedule (EPPS) (Edwards, 1963), containing 28 achievement and 22 filler items, was administered. Significant correlations between the EPPS and the Thematic Apperception Test (Grant, Katovsky, \& Bray, 1967), the Personality Research Form (Edwards, Abbot, \& Klockars, 1972), the French Test of Insight (Shaw, 1961), and the Graphic Expression Technique (Weinstein, 1969) have been reported. These correlations indicate that the EPPS is a valid measure of achievement motivation (Fineman, 1977).

Given the purpose of the study and the nature of the hypotheses, stepwise multiple regression was considered the best method of data analysis. The SPSS program (Nie, Hull, Jenkins, Steinbrenner, \& Bent, 1975) for the stepwise solution of multiple-regression analyses was used. The order in which the variables are placed in the equation was determined by the criteria established by this program. Essentially, the first variable entered is the one with the highest correlation with the criterion variable. The next variable entered into the equation is the one variable among those remaining with the highest correlation with the criterion variable, once the effects of the first variable have been partialled out. The program continues in this fashion until all the variables that contribute to total variance are entered.

In order to test the hypotheses, one stepwise multipleregression analysis was performed. In it, the variables of sex, family size, birth order, and father's age were predictor variables, and the need for achievement scores served as the criterion variable. Sex and birth order (coded first, middle, and last) became dummy variables, while family size (number of siblings plus one) and father's age (father's current age minus child's current age) were both continuous variables. Because of abnormalities in the distribution of the EPPS scores, they underwent an exponential ( $\left.\mathrm{e}^{\text {arg }}\right)$ transformation.

\section{RESULTS}

The results of the regression analysis $(\mathrm{N}=1,041)$ are presented in Table 1. They support the notion that father's age is a significant predictor of need achievement. This factor is the only one of the predictors yielding an effect significant at conventional levels. The correlation between need achievement and father's age indicates that younger fathers are associated with greater achievement motivation in their children. The next two variables entered into the equation yield Fs of borderline significance. The correlations associated 
Table 1

Summary of Stepwise Regression Analysis

\begin{tabular}{clccc}
\hline Step & Predictor & Multiple R & Simple R & $\begin{array}{c}\text { F to Enter } \\
\text { or Remove }\end{array}$ \\
\hline 1 & Father's Age & .09 & -.09 & $8.47^{* *}$ \\
2 & Family Size & .11 & -.01 & $3.23^{*}$ \\
3 & Sex & .12 & .05 & $3.39^{*}$ \\
4 & Birth Order & .13 & .01 & .66 \\
\hline
\end{tabular}

*.05<p<.10. $\quad * * p<.01$.

with family size and sex indicate, respectively, that members of smaller families and males have higher achievement motivation than members of larger families and females.

\section{DISCUSSION}

The results of this study point to the importance of father's age in determining achievement motivation. Within the middle class, younger fathers are positively related to achievement motivation in their children.

Father's age can be conceptualized as having its effect on the development of achievement motivation through two mechanisms: (1) the imposition of high standards, and (2) modeling. It is argued here that younger fathers impose higher standards of behavior on their children. This may be due to their understanding of the father role, as suggested in the introduction, or it may be simply due to their general inexperience with children, which leads them to be less accepting of children's behavior. The second mechanism that could bring about this effect concerns modeling. Since older adults have been found to possess less achievement motivation than younger ones, it is likely that younger fathers model more achievementrelated behaviors than older fathers. Further research should examine the mechanisms underlying the father's age effect.

Family size was found to be negatively related to achievement motivation, although the additional variance accounted for by this variable was of borderline significance. One interpretation of the family size effect is that parents who have higher achievement motivation have fewer children. Another interpretation is that growing up in a small family provides experiences conducive to developing high achievement motivation.

Also, a sex effect of borderline significance was found. Males scored higher than females. This is consistent with the current fact that, as adults, females achieve less than males.

Birth order was remarkably unsuccessful in predicting achievement motivation. There was no increment in the amount of variance accounted for when birth order was entered into the equation. It is possible that previous investigators found a relationship between birth order and achievement motivation because they failed to consider father's age. Inevitably, fathers are younger at the birth of earlier than later borns. Future research aimed at investigating birth order effects in achievement should include father's age as a variable so that this alternate explanation for birth order effects in achievement motivation can be tested.

\section{REFERENCES}

Alper, T. G. Achievement motivation in college women. American Psychologist, 1974, 29, 194-203.

Atkinson, J. W. (Ed.). Motives in fantasy, action, and society: $A$ method of assessment and study. Princeton, N.J: Van Nostrand, 1958.

Bandura, A., Grusec, J. E., \& Menlove, F. L. Some social determinants of self-monitoring reinforcement systems. Journal of Personality and Social Psychology, 1967, 5, 449-455.

BRELAND, H. M. Birth order family configuration, and verbal achievement. Child Development, 1974, 45, 1011-1019.

Child, I. L., Storm, T., \& Veroff, J. Achievement themes in folk tales related to socialization practice. In J. W. Atkinson (Ed.), Motives in fantasy, action, and society: $A$ method of assessment and study. Princeton, N.J: V an Nostrand, 1958.

Clemente, R., \& Sayer, W. Life satisfaction in the United States. Social Forces, 1976, 54, 621-631.

CONDRY, J., \& DYER, S. Fear of success: Attribution of cause to the victim. Journal of Social Issues, 1976, 32, 63-84.

Crandall, V. C., \& Battle, E. S. The antecedents and adult correlates of academic and intellectual achievement effort. In J. P. Hill (Ed.), Minnesota symposia on child psychology 4. Minneapolis: University of Minnesota Press, 1970.

CRandall, V. J. Achievement. In H. W. Stevenson (Ed.), Child psychology: Sixty-second yearbook of the National Society for the Study of Education. Chicago: University of Chicago Press, 1963.

Douvan, E. Social status and success strivings. In J. W. Atkinson (Ed.), Motives in fantasy, action, and society: $A$ method of assessment and study. Princeton, N.J: Van Nostrand, 1958.

EDW ARDs, A. L. Edwards personal preference schedule. New York: Psychological Corporation, 1963.

Edwards, A. L., Abbott, R. D., \& Klockars, A. J. A factor analysis of the EPPS and PFR personality inventories. Educational Psychology Measurement, 1972, 32, 23-39.

Fineman, $\mathrm{S}$. The achievement motive construct and its measurement: Where are we now? British Journal of Psychology, $1977,68,1-22$.

Grant, D. L., Katovsky, W., \& Bray, D. W. Contributions of projective techniques to asessment of managerial potential. Journal of Applied Psychology, 1967, 51, 226-232.

Hoffman, L. W. Early childhood experiences and women's achievement motives. Journal of Social Issues, 1972, 28, 129-156.

KaGAN, J., \& FreEman, M. Relation of childhood intelligence, maternal behaviors, and social class to behavior during adolescence. Child Development, 1963, 34, 899-911.

Kagan, J., \& Moss, H. A. Birth to maturity. New York: Wiley, 1962.

LENNEY, E. Women's self-confidence in achievement settings. Psychological Bulletin, 1977, 84, 1-13.

McClelland, D. C. The achieving society. Princeton, N.J: Van Nostrand, 1961.

McClelland, D. C., Atkinson, J. W., Clatk, R. A., \& LOWELl, E. L. The achievement motive. New York: AppletonCentury-Crofts, 1953.

Mischel, W., \& Liebert, R. M. Effects of discrepancies between observed and imposed reward criteria on their acquisition and transmission. Journal of Personality and Social Psychology, 1966, 3, 45-53.

Nie, N. H., Hull, C. H., Jenkins, J. G., Steinbrenner, K., \& BENT, D. H. SPSS: Statistical package for the social sciences (2nd ed.). New York: McGraw-Hill, 1975.

NyDEgGER, C. N. Timing of fatherhood: Role perception and socialization (Doctoral dissertation, Pennsylvania State University, 1973). Dissertation Abstracts International, 1973, 34, 5355-A.

Rosen, B. C. The achievement syndrome: A psychocultural dimension of social stratification. In J. W. Atkinson (Ed.), Motives in fantasy, action, and society: $A$ method of assessment and study. Princeton, N.J: Van Nostrand, 1958.

Rosen, B. C., \& D'ANDrade, R. G. The psychological origins of achievement motivation. Sociometry, 1959, 22, 185-218.

Shannan, J., \& Sharon, M. Personality and functioning of Israeli males during the middle years. Human Development, $1965,8,2-15$.

SHAw, M. C. Need achievement scales as predictors of academic success. Journal of Educational Psychology, 1961, 52, 282-285. 
Stein, A. H., \& Barley, M. M. The socialization of achievement orientation in females. Psychological Bulletin, 1973, 80, 345-366.

Tresemer, D. A cumulative record of research on "fear of success.” Sex Roles, 1976, 2, 217-236.

WEINSTEIN, M. S. Achievement motivation and risk performance. Journal of Personality and Social Psychology, 1969, 13, 153-172.

Winterbottom, M. R. The relation of need for achievement to learning experiences in independence and mastery. In J. W. Atkinson (Ed.), Motives in fantasy, action, and society: $A$ method of assessment and study. Princeton, N.J: Van Nostrand, 1958.

ZAJONC, R. B. Figure configuration and intelligence. Science, 1976, 192, 227-236.

(Received for publication January 15, 1979.) 